\title{
Implementation of Last Planner System for Improving the Construction Process
}

\author{
S M Abdul Mannan Hussain ${ }^{1}$, Dr. Seshadri Sekhar T ${ }^{2}$, Dr B.S.R.K Prasad ${ }^{3}$ \\ ${ }^{1}$ Research Scholar, Department of Civil Engineering \\ GITAM University, Hyderabad campus, Telangana, India. \\ sohailkhn248@gmail.com \\ ${ }^{2}$ Professor and Dean of NICMAR \\ Hyderabad campus, Telangana, India \\ ss.tirumala@gmail.com \\ ${ }^{3}$ Head of the Department \& Professor, Department of Civil Engineering \\ GITAM University, Hyderabad campus,Telangana, India. \\ hodcivil_hydcampus@gitam.in
}

\begin{abstract}
The aim of this research is to improve the construction planning practice and enhance site management by implementing the Last Planner System (LPS). LPS was implemented in a residential building construction project through an action research process. To reach this, design science research strategy was undertaken with different data collection methods. The data collection methods included questionnaire survey, direct and indirect observations and interviews with the construction team. However, the construction industry is associated with a number of challenges which impair its performance. These challenges were grouped and classified into six major barriers: these include: supervision and quality control, fluctuation and variations, subcontractor involvement, resistance to change, cultural issues, and lengthy approvals. The research findings identify benefits including improved construction planning; intensify site management and good communication and coordination between the parties involved.
\end{abstract}

Keywords - Last Planner System, Residential building construction, Percent Plan Complete, Design science research.

\section{INTRODUCTION}

Last Planner System (LPS) is a system of production control that emphasizes the relationship between scheduling and production control to improve flow of resources (Ballard, 2000; Fewings, 2013). The Last Planner is the person for operational planning, that is, the structuring of product design to facilitate improved work flow, and production unit control, that is, the completion of individual assignments at the operational level (Ballard, 2000). People, information, equipment, materials, prior work, safe space and safe working environment are the seven flows required to come together at the workplace to enable construction transformation to flow. The Last Planner System (LPS) manages all seven flows by building relationships, creating conversations, and by securing commitments to action at the right level at right time throughout the process (Mossman 2008).

According to Ballard and Howell (1994), the use of Lean-based tools like Last Planner reduces accident rates. The aim of Last Planner System according to Ballard (1997) is to improve productivity by eliminating barriers to workflow. One of the main advantages is that it replaces optimistic planning with realistic planning by assessing the last planners' performance based on their ability to achieve their commitments (Salem et. al, 2006).

\section{LITERATURE REVIEW}

Usama Hamed Issa (2013) stated that many construction projects involve different risk factors which have many impacts on time-overrun. This study suggests and applies a new approach for reducing risk factors and its effect on time using lean construction process. Assessing the effect of using the new tool like Percent Expected Timeoverrun (PET) and the other is Percent Plan Completed (PPC). The very important risk factors are also identified and evaluated, while PET quantified at the starting stage of the project and during the project execution stage a quantification model used for time-overrun quantification.

Mohd Arif Marhani et al. (2013) proposed that sustainability through Lean Construction Approach. The aim of this research is to give the basic fundamental concept of Lean construction and highlight the main barriers of its implementation process. A wide and extensive literature reviews conducted by retrieving articles related from journals ranging from the year 1992 to June 2012. From the various review of literature search, it identified that Lean construction ability in improving the project performance especially in reducing site waste, construction 
stipulated time and overall cost of the construction, improving quality of the projects and environmental as whole.

Ojo et al (2014) established a qualitative approach to analyze barriers in implementing green supply chain management in Nigeria. The results revealed the following barriers: lack of public awareness, lack of knowledge and environmental impact, poor commitment by top management, lack of legal enforcement by government, lack of resources, lack of sustainable practices, lack of market, and lack of information sharing, lack of demand. He stated that the teaching techniques of lean construction and project management training programs conducted for motivating the research scholars and practitioners. It was also concluded that the success of the training Course is reflecting the opportunities for improvement identified between editing and publishing, made possible through the feedback collected from participants.

Raghavan et al. (2014) proposed implementing the Lean Concepts on Indian Construction Sites. Construction industry in India has been on a rapid growth path lately and increasing efficiency and profitability has been a key concern. IIT Madras, an educational institution, had recently taken up a program as a challenge to give training and implementation of Lean construction process in few trial projects through seminar halls and webinar based training course, reporting in technical formats, monitoring and motivating by site visits and carrying out reviews regularly. Construction sites encouraged to adopt the Last Planner System technique and to use other Lean tools in-depth help from the Faculty. It was also concluded that by implementing the lean concept and practices in Indian construction projects; will cut the overall project time and will improve the project planning and scheduling.

\section{RESEARCH METHOD}

Having reviewed the relevant literature for the research, it is now imperative to demonstrate the philosophical principles behind the research and how it was designed to address its objectives. This describes the methodology used in carrying out this research. It introduces Design Science Research (DSR) methods and further justifies the adoption of this research method employed to meet the objectives of this research. Design science research approach is introduced as an alternative approach to the traditional research methods employed within construction management. It also discusses the data collection and evaluation processes utilized in carrying out this research. DSR in itself is an innovative research method; hence it serves as a contribution to knowledge in whatever fields it is applied.DSR focuses on the development (construction) of a solution and its evaluation (Hevneret al., 2004). It allows for several data collection tools rather than a single method of data collection. Hence, multiple sources of data collection were employed in this research. It included: interview, focus groups, participant and non-participant observation, survey questionnaires and documentary analysis. The data was evaluated based on the utility, quality and efficacy of the information gathered.

\section{LPS IMPLEMENTATION}

\section{A. Case background}

The case study was carried out in an on-going construction project at Gachibowli located at the outskirts of Hyderabad city. The project is for the construction of proposed Amazon Development Centre India Private Limited at Hyderabad with all facilities. It is located at about $20 \mathrm{~km}$ away from Secunderabad, the site is opposite to Wave rock building which serves as a landmark to the site, and it is $5 \mathrm{~km}$ away from the Outer Ring Road at Gachibowli Exit.

The data for the research work was gathered in three phases which consisted of:

\section{B. Pre-implementation phase}

$$
\begin{aligned}
& >\text { Pre-implementation } \\
& >\text { Implementation, and } \\
& >\text { Post-implementation phase. }
\end{aligned}
$$

The data collected from the contractor during the observation and interview session in this section is discussed. The researcher started with the non-participant observation, followed by the interview, which served as a validation of the findings obtained from the observation process. These findings from the contractor are discussed below.

TABLE I. Phases of data collection process

\begin{tabular}{|c|c|l|l|}
\hline Phase 1 & Pre-Implementation & $\begin{array}{l}\text { Non-Participant Observations } \\
\text { Interviews }\end{array}$ \\
\hline Phase 2 & Implementation & $\bullet$ & Participant Observations \\
& Post-Implementation & $\bullet$ & Questionnaires \\
\hline Phase 3 & Pocumentary Analysis \\
\hline
\end{tabular}


TABLE II. Findings with the non-participant observations with the Contractor

\begin{tabular}{|c|c|}
\hline Site Activities & Contractor - Shapoorji pallonji \&Co Pvt. Ltd. \\
\hline $\begin{array}{c}\text { Planning practice in terms of } \\
\text { labor and material schedules. }\end{array}$ & $\begin{array}{c}\text { Labor and Materials were properly coordinated in an arranged } \\
\text { manner as per the site map. }\end{array}$ \\
\hline Frequency of Site Meetings. & Daily and regular site meetings. \\
\hline Site Coordination. & Work is properly structured but partly properly coordinated. \\
\hline $\begin{array}{c}\text { Communication and } \\
\text { Relationships. }\end{array}$ & $\begin{array}{c}\text { Good communication channel with modern communication } \\
\text { gadgets as well as a good coordinal relationship between the } \\
\text { projects participants. }\end{array}$ \\
\hline
\end{tabular}

TABLE III. Findings from the Interview of the Contractor

\begin{tabular}{|c|c|}
\hline Site Activities & Contractor -Shapoorji pallonji \&Co Pvt. Ltd. \\
\hline $\begin{array}{c}\text { Current Planning - } \\
\text { Frequency of Site Meetings }\end{array}$ & Meetings are held daily \\
\hline Control - Site Manager & Site Engineers coordinate different sections of the site \\
\hline Communication Gadgets & Communication Gadgets like Walkie-Talkies were used. \\
\hline $\begin{array}{c}\text { Project Management } \\
\text { Systems in Place }\end{array}$ & Critical Path Methods (CPM) \\
\hline Lean Awareness & Aware of Lean Construction but have never practiced it in work. \\
\hline
\end{tabular}

\section{C.Implementationphase}

The researcher introduced the concepts of Lean Construction and the Last Planner System to the contractor carrying out the construction of the Amazon IT services, Hyderabad. The contractor (Shapoorji Pallonji \& Co Pvt. Ltd.) was keen on improving the way they previously coordinated, planned and controlled site activities. The implementation commenced with a brief seminar on the concepts of Lean construction and the Last Planner System. The workshop was held on the $15^{\text {th }}$ April, 2016, and the employees of Shapoorji Pallonji \& Co Pvt. Ltd. ensured that all the project participants including its subcontractors were a part of this seminar.

From Table-IV and Figure-1, the average PPC is 48.72 \% which is a very low PPC. The reasons for the incomplete assignments that led to a low PPC is shown in figure-2.

TABLE IV. Comparison of 4 weeks of PPC (20/04/2016 - 17/05/2016)

\begin{tabular}{|c|c|c|c|c|}
\hline Weeks & $\begin{array}{c}\text { No. Of Completed } \\
\text { Tasks }\end{array}$ & $\begin{array}{c}\text { No. Of Incomplete } \\
\text { Tasks }\end{array}$ & Total Tasks & PPC \\
\hline $20 / 04 / 2016-26 / 04 / 2016$ & 6 & 5 & 11 & $54.55 \%$ \\
\hline $27 / 04 / 2016-03 / 05 / 2016$ & 5 & 4 & 9 & $55.56 \%$ \\
\hline $04 / 05 / 2016-10 / 05 / 2016$ & 4 & 6 & 10 & $40.00 \%$ \\
\hline $11 / 05 / 2016-17 / 05 / 2016$ & 4 & 5 & 9 & $44.44 \%$ \\
\hline & 19 & 20 & 39 & $\mathbf{4 8 . 7 2} \%$ \\
\hline
\end{tabular}




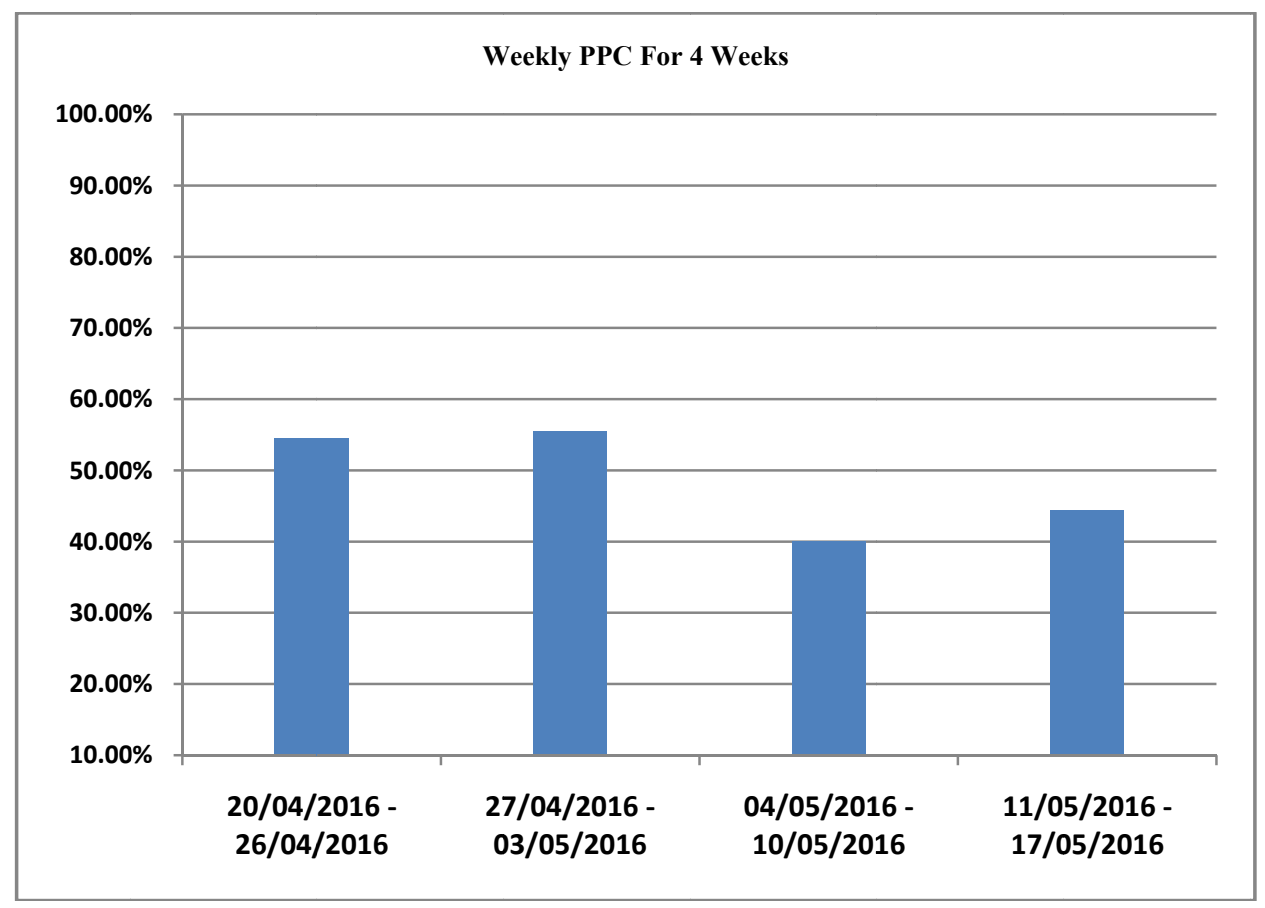

Fig.1.Weekly PPC for Four Weeks (20/04/2016 - 17/05/2016)

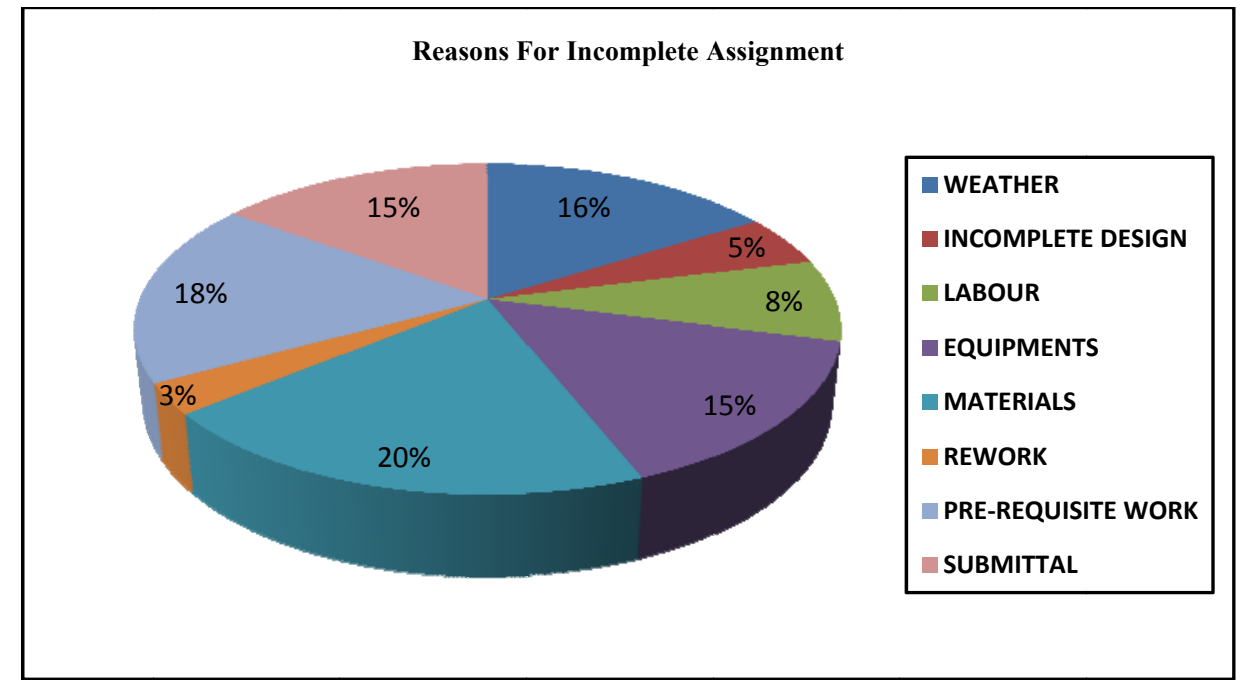

Fig.2. Reasons for incomplete assignment for first look-ahead schedule (20/04/2016 - 17/05/2016)

TABLE V. Comparison of 4 weeks of PPC (18/05/2016 - 14/06/2016)

\begin{tabular}{|c|c|c|c|c|}
\hline Weeks & $\begin{array}{c}\text { No. Of Completed } \\
\text { Tasks }\end{array}$ & $\begin{array}{c}\text { No. Of Incomplete } \\
\text { Tasks }\end{array}$ & Total Tasks & PPC \\
\hline $18 / 05 / 2016-24 / 05 / 2016$ & 7 & 5 & 13 & $58.33 \%$ \\
\hline $25 / 05 / 2016-31 / 05 / 2016$ & 6 & 6 & 12 & $50.00 \%$ \\
\hline $01 / 06 / 2016-07 / 06 / 2016$ & 9 & 5 & 16 & $64.29 \%$ \\
\hline $08 / 06 / 2016-14 / 06 / 2016$ & 6 & 6 & 12 & $50.00 \%$ \\
\hline & 28 & 22 & 50 & $56 \%$ \\
\hline
\end{tabular}




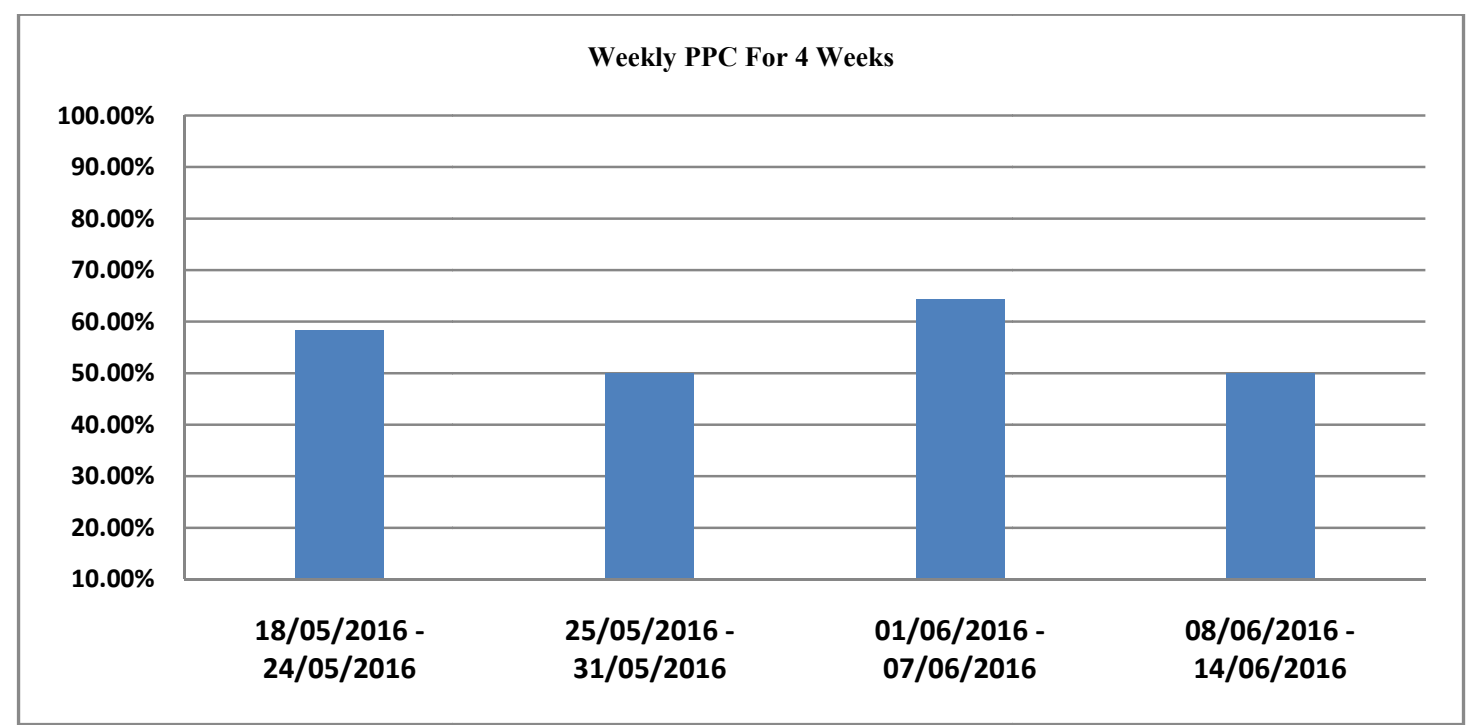

Fig.3.Weekly PPC for Four Weeks (18/05/2016 - 14/06/2016)

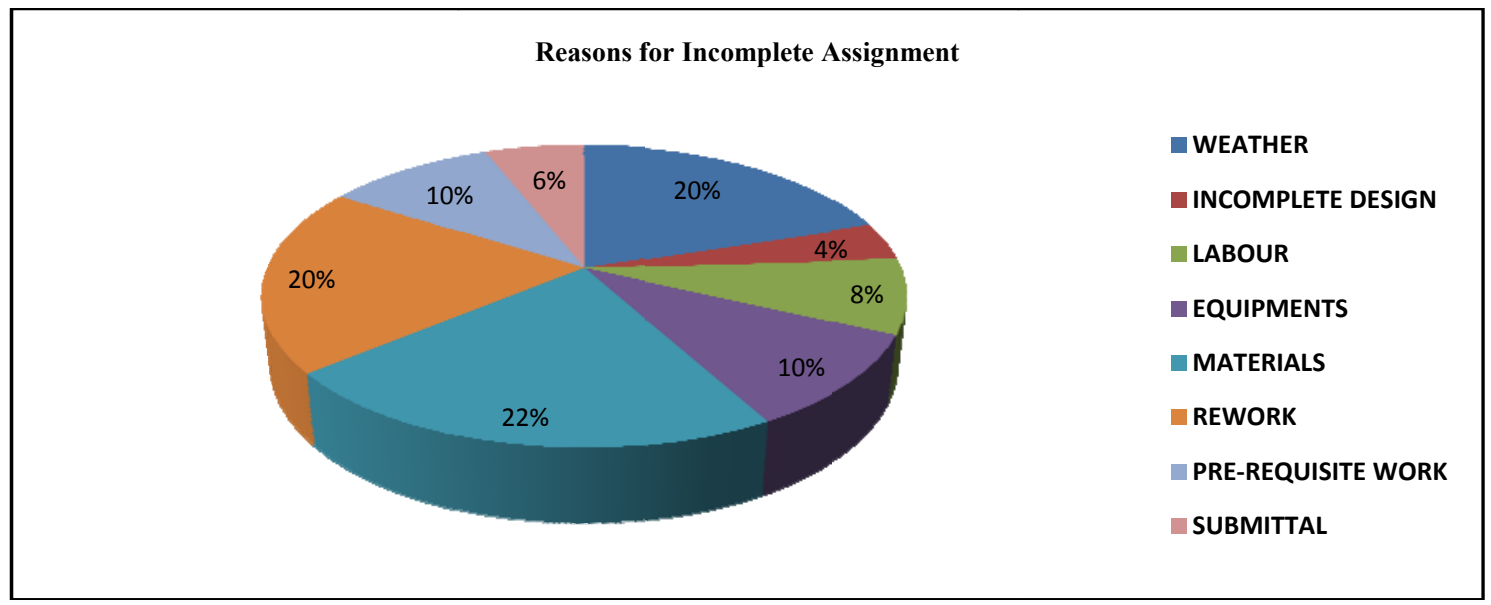

Fig.4.Reasons for incomplete assignment for second look-ahead schedule (18/05/2016 - 14/06/2016)

Furthermore, table 5 indicates the PPC's recorded within the second look-ahead schedule (second month) of the implementation. The average PPC recorded in this (i.e. second) month was 56\%. This was higher than the average PPC (48.72\%) recorded in the first month of the observations. An improvement in the average PPC's was observed as each team saw the importance of keeping reliable promises.

The PPC's for the third look-ahead schedule is presented in table 6 and figure 5 shows a noticeable improvement on the PPC's and the average PPC recorded within these four weeks is $66.04 \%$.

TABLE VI. Comparison of 4 Weeks of PPC (15/06/2016 - 12/07/2016)

\begin{tabular}{|c|c|c|c|c|}
\hline Weeks & $\begin{array}{c}\text { No. of Completed } \\
\text { Tasks }\end{array}$ & $\begin{array}{c}\text { No. of Incomplete } \\
\text { Tasks }\end{array}$ & $\begin{array}{c}\text { Total } \\
\text { Tasks }\end{array}$ & PPC \\
\hline $15 / 06 / 2016-21 / 06 / 2016$ & 10 & 2 & 12 & $83.33 \%$ \\
\hline $22 / 06 / 2016-28 / 06 / 2016$ & 9 & 7 & 16 & $56.25 \%$ \\
\hline $29 / 06 / 2016-05 / 07 / 2016$ & 8 & 6 & 14 & $57.14 \%$ \\
\hline $06 / 07 / 2016-12 / 07 / 2016$ & 8 & 3 & 11 & $72.73 \%$ \\
\hline & 35 & 18 & 53 & $66.04 \%$ \\
\hline
\end{tabular}




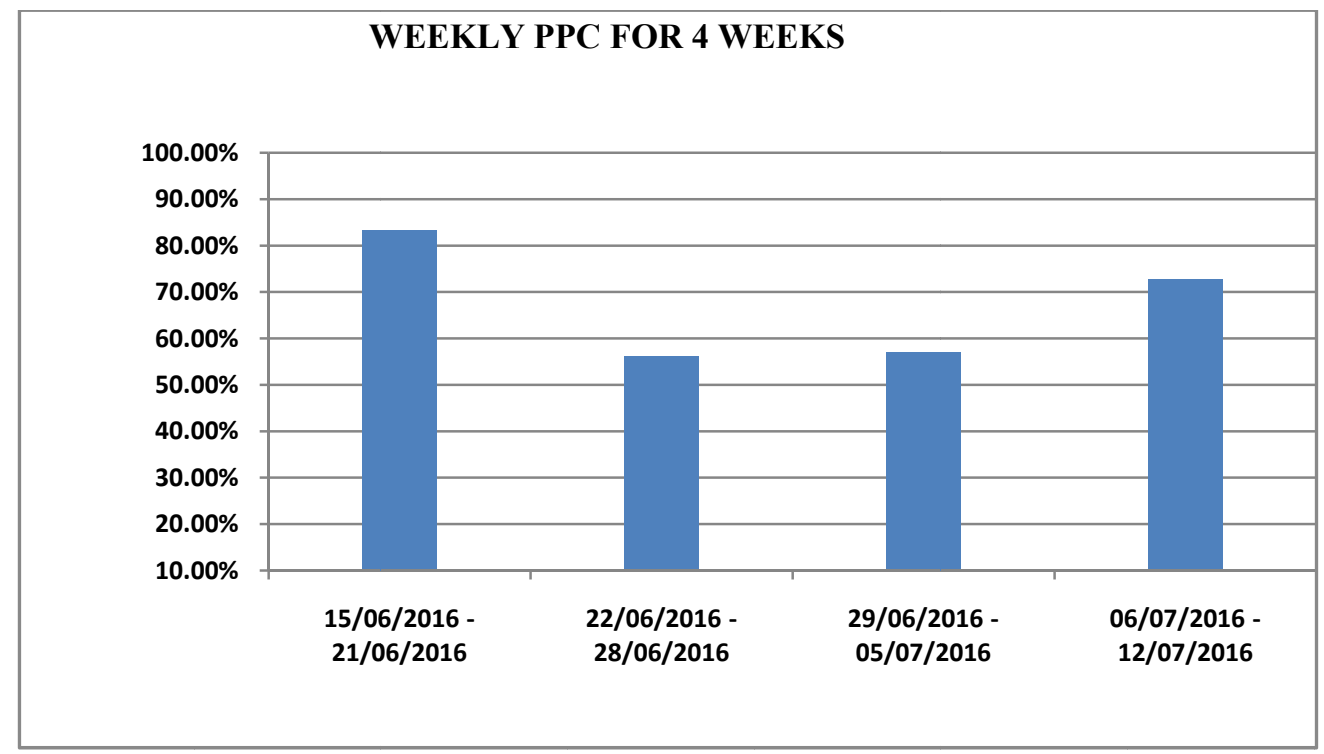

Fig.5. Weekly PPC for 4 Weeks (15/06/2016 - 12/07/2016)

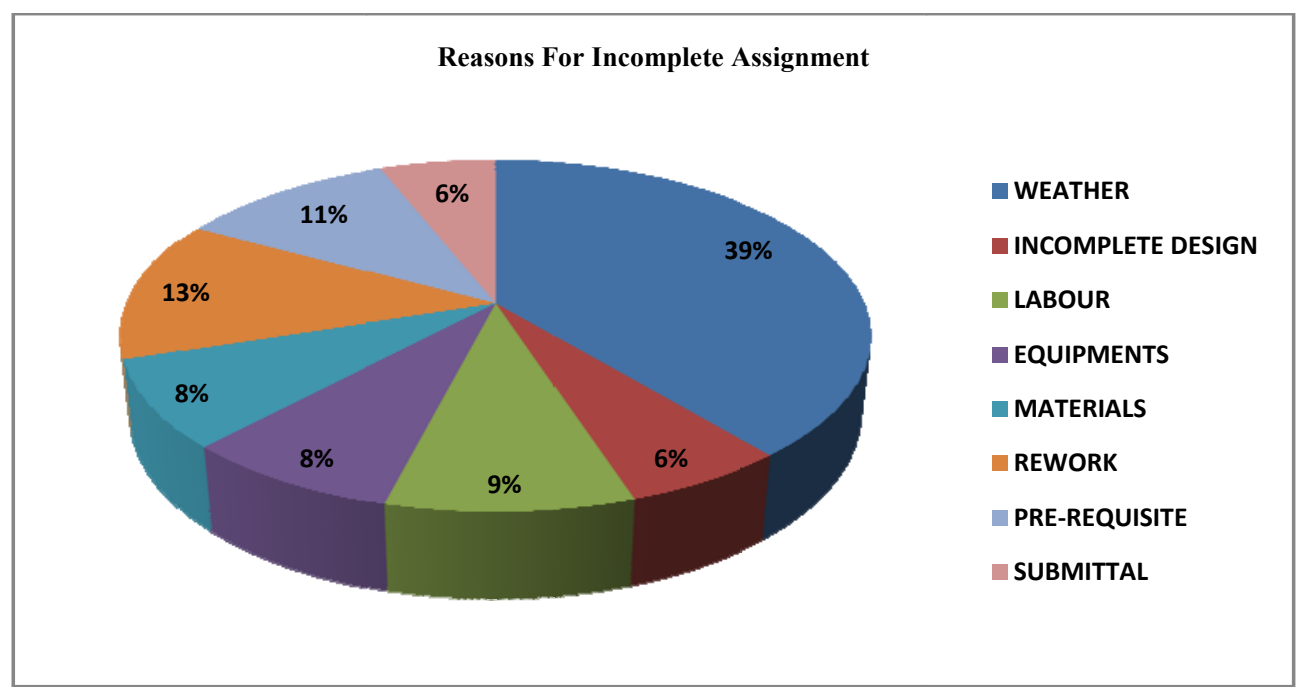

Figure.6.Reasons for incomplete assignment for third look-ahead schedule (15/06/2016 - 12/07/2016)

\subsection{Post Implementation Process}

A.QuestionnaireSurveysQuestionnaire surveys were administered to the project participants to evaluate the Last Planner System implementation process. The questionnaire was classified into four sections (section A - D). The first section (i.e. Section A) focused on getting an overview of the outcome of the implementation. Whereas, the second section (i.e. Section B) focused primarily on the barriers of the implementation process. The third section (i.e.Section C) gave attention to the critical success factors of the implementation process. Furthermore, the last section (i.e. Section D) dwelt on the benefits perceived on implementing Last Planner System on the case project. The respondents for the questionnaire comprised of the contractor's team, the employer's and the suppliers. A percentage breakdown of the respondents is shown below in Table 7 and the details of the questionnaires and their corresponding responses are discussed below.

Out of the 22 employees involved in the survey 24 (96\%) provided responses accordingly. Out of the respondent, 13 (54.17\%), 4 (16.67\%), 4 (16.67\%) and 3 (12.50\%) are respectively contractor's team, client's team, sub-contractor's team and the supplier's team. 
TABLE.VII. Respondents of the questionnaire for Case Study

\begin{tabular}{|c|c|c|}
\hline Respondents Total & 22 & $100 \%$ \\
\hline Contractor's Team & 13 & $59.09 \%$ \\
\hline Consultant Team & 2 & $9.09 \%$ \\
\hline Subcontractor's Team & 4 & $18.18 \%$ \\
\hline Supplier's Team & 3 & $13.63 \%$ \\
\hline
\end{tabular}

\section{1)Section- $A$}

The question that whether Last Planner System is effective within the project or not, was examined by the 22 respondents under the 5 Point Likert Scale. The percentage of those accepting the effectiveness of Last Planner System within the project is $100 \%$.

Furthermore, it was identified that $100 \%$ of the respondents agreed to the statement that as compared to their previous projects, the results were quiet satisfactory this time as shown in Table 8. In the same way, the question that whether the weekly work plans or PPC's were useful to the implementation was carefully examined, 91\% respondents agreed on the usefulness of weekly plans and PPC while the remaining $9 \%$ respondents were indifferent or disagreed.

Additionally, from the survey results of the respondents felt that the process of implementing Last Planner System was not at all difficult and they felt it was easy to carry out the implementation of Last Planner System

TABLE VIII. Overview of the Implementation (Section A)

\begin{tabular}{|c|c|c|c|c|c|c|c|c|c|c|c|c|}
\hline \multirow{2}{*}{ Sr.No. } & \multirow{2}{*}{ Reasons } & \multicolumn{11}{|c|}{ Weighting Frequency (F) } \\
\hline & & 1 & 2 & 3 & 4 & 5 & $\sum \mathbf{f}$ & $\overline{\mathbf{x}}$ & RII & Rank & Rating & \% Rating \\
\hline 01. & $\begin{array}{l}\text { LPS was very } \\
\text { effective within this } \\
\text { project. }\end{array}$ & 0 & 0 & 0 & 15 & 7 & 22 & 4.32 & 0.86 & 3 & $\begin{array}{l}\text { Very } \\
\text { High } \\
\text { rating }\end{array}$ & 100 \\
\hline 02. & $\begin{array}{l}\text { The results obtained } \\
\text { from the } \\
\text { implementation were } \\
\text { satisfactory as } \\
\text { compared to the } \\
\text { previous projects. }\end{array}$ & 0 & 0 & 0 & 4 & 18 & 22 & 4.81 & 0.96 & 1 & $\begin{array}{l}\text { Very } \\
\text { High } \\
\text { rating }\end{array}$ & 100 \\
\hline 03. & $\begin{array}{c}\text { The weekly work } \\
\text { plans and PPC were } \\
\text { very useful. }\end{array}$ & 0 & 2 & 0 & 4 & 16 & 22 & 4.36 & 0.87 & 2 & $\begin{array}{l}\text { Very } \\
\text { high } \\
\text { rating }\end{array}$ & 91 \\
\hline 04. & $\begin{array}{l}\text { Difficulty to carry } \\
\text { out the } \\
\text { implementation. }\end{array}$ & 8 & 10 & 4 & 0 & 0 & 22 & 1.81 & 0.36 & 4 & $\begin{array}{l}\text { Low } \\
\text { rating }\end{array}$ & 0 \\
\hline
\end{tabular}

2) Section-B:

The questions in this section are primarily focussed on the barriers that were faced during the implementation of Last Planner System. The questions were formatted using a 5-Point Likert Scale for each attribute attached to the question. The attributes were divided into 6 options identifying possible barriers to the Last Planner System implementation.

From table 9, it was observed that $64 \%$ agreed to the option that supervision/quality control was a barrier to the implementation, while $32 \%$ were of the opinion that fluctuations and variations were barriers during the implementation. Furthermore, 59\% indicated that employer's involvement was a barrier faced by the company during the implementation.

In the same vein, $82 \%$ agreed that resistance to change was a major barrier. While another $100 \%$ were of the opinion that cultural issues was a barrier. Finally, $86 \%$ agreed that lengthy approval procedure by the client was a barrier to the implementation process. 
TABLE IX. Barriers during the Implementation (Section B)

\begin{tabular}{|c|c|c|c|c|c|c|c|c|c|c|c|c|}
\hline \multirow{2}{*}{$\begin{array}{l}\text { Sr. } \\
\text { No. }\end{array}$} & \multirow[t]{2}{*}{ Barriers } & \multicolumn{11}{|c|}{ Weighting Frequency (F) } \\
\hline & & 1 & 2 & 3 & 4 & 5 & $\sum \mathbf{F}$ & $\overline{\mathbf{x}}$ & RII & Rank & Rating & $\begin{array}{c}\% \\
\text { Rating }\end{array}$ \\
\hline 01. & $\begin{array}{c}\text { Poor Supervision \& } \\
\text { Quality Control } \\
\end{array}$ & 0 & 2 & 6 & 13 & 1 & 22 & 3.59 & 0.72 & 5 & $\begin{array}{l}\text { High } \\
\text { rating }\end{array}$ & 64 \\
\hline 02. & $\begin{array}{c}\text { Fluctuations \& } \\
\text { Variations } \\
\end{array}$ & 0 & 5 & 10 & 6 & 1 & 22 & 3.16 & 0.63 & 6 & $\begin{array}{l}\text { High } \\
\text { rating }\end{array}$ & 32 \\
\hline 03. & $\begin{array}{l}\text { Employer's } \\
\text { Involvement }\end{array}$ & 0 & 3 & 6 & 9 & 4 & 22 & 3.63 & 0.73 & 4 & $\begin{array}{l}\text { High } \\
\text { rating }\end{array}$ & 59 \\
\hline 04. & $\begin{array}{l}\text { Resistance to } \\
\text { Change }\end{array}$ & 0 & 0 & 4 & 14 & 4 & 22 & 4 & 0.8 & 3 & $\begin{array}{c}\text { Very High } \\
\text { rating }\end{array}$ & 82 \\
\hline 05. & Cultural Issues & 0 & 0 & 0 & 16 & 6 & 22 & 4.27 & 0.85 & 2 & $\begin{array}{c}\text { Very High } \\
\text { rating }\end{array}$ & 100 \\
\hline 06. & $\begin{array}{l}\text { Length approval } \\
\text { issues by Client }\end{array}$ & 0 & 0 & 3 & 9 & 10 & 22 & 4.31 & 0.86 & 1 & $\begin{array}{c}\text { Very High } \\
\text { rating }\end{array}$ & 86 \\
\hline
\end{tabular}

3) Section-C:

This section evaluates the critical success factors of implementing Last Planner System within this case study. The attributes for the question raised in this section, were possible success factors derived from the literature reviews and from the site observations during the implementation. Table 10 shows the views of the respondents.

Here, $100 \%$ respondents agreed that training and empowering last planners were a critical success factor (CSF) to the implementation. In the same vein, $91 \%$ respondents agreed that involvement of all stakeholders (i.e. team work) was a major CSF to the implementation. Similarly, $100 \%$ were of the opinion that motivating people was a CSF to the process, while $100 \%$ affirmed that top managements support was one of the critical success factors. On the other hand, $82 \%$ indicated that managing resistance to change was a CSF. Similarly, 95\% agreed that having a close relationship with suppliers was a CSF for the implementation. Conversely, $73 \%$ of the respondents were of the opinion that having appropriate human capital was a CSF, while the remaining $27 \%$ respondents were either indifferent or disagreed that having appropriate human capital was CSF.

Table X. Critical Success factors to the Implementation (Section C)

\begin{tabular}{|c|c|c|c|c|c|c|c|c|c|c|c|c|}
\hline \multirow[b]{2}{*}{ Sr.No. } & \multirow[b]{2}{*}{ Factors } & \multicolumn{11}{|c|}{ Weighting Frequency (F) } \\
\hline & & 1 & 2 & 3 & 4 & 5 & $\sum \mathbf{F}$ & $\overline{\mathbf{x}}$ & RII & Rank & Rating & $\begin{array}{c}\% \\
\text { Rating }\end{array}$ \\
\hline 01. & $\begin{array}{l}\text { Training \& } \\
\text { Empowering Last } \\
\text { Planners. }\end{array}$ & 0 & 0 & 0 & 18 & 4 & 22 & 4.18 & 0.83 & 3 & $\begin{array}{l}\text { Very } \\
\text { High } \\
\text { rating }\end{array}$ & 100 \\
\hline 02. & $\begin{array}{l}\text { Involvement of all } \\
\text { Stake Holders } \\
\text { (Team Work). }\end{array}$ & 0 & 0 & 2 & 18 & 2 & 22 & 4 & 0.8 & 6 & $\begin{array}{l}\text { Very } \\
\text { High } \\
\text { rating }\end{array}$ & 91 \\
\hline 03. & $\begin{array}{l}\text { Motivating People } \\
\text { to make changes. }\end{array}$ & 0 & 0 & 0 & 10 & 12 & 22 & 4.54 & 0.9 & 1 & $\begin{array}{l}\text { Very } \\
\text { High } \\
\text { rating }\end{array}$ & 100 \\
\hline 04. & $\begin{array}{c}\text { Having the } \\
\text { appropriate Human } \\
\text { Capital. }\end{array}$ & 0 & 2 & 4 & 12 & 4 & 22 & 3.81 & 0.76 & 7 & $\begin{array}{l}\text { High } \\
\text { rating }\end{array}$ & 73 \\
\hline 05. & $\begin{array}{l}\text { Top Management } \\
\text { Support. }\end{array}$ & 0 & 0 & 0 & 12 & 10 & 22 & 4.45 & 0.89 & 2 & $\begin{array}{l}\text { Very } \\
\text { High } \\
\text { rating }\end{array}$ & 100 \\
\hline 06. & $\begin{array}{l}\text { Manage Resistance } \\
\text { to Change. }\end{array}$ & 0 & 2 & 2 & 10 & 8 & 22 & 4.09 & 0.82 & 5 & $\begin{array}{l}\text { Very } \\
\text { High } \\
\text { rating } \\
\end{array}$ & 82 \\
\hline 07. & $\begin{array}{l}\text { Close Relations } \\
\text { with Suppliers. }\end{array}$ & 0 & 0 & 1 & 18 & 3 & 22 & 4.09 & 0.82 & 4 & $\begin{array}{l}\text { Very } \\
\text { High } \\
\text { rating }\end{array}$ & 95 \\
\hline
\end{tabular}




\section{4) Section- $D$ :}

This section focused on the benefits of implementing Last Planner System in construction. Ten benefits were suggested as possible benefits of implementing Last Planner System and respondents were expected to express their views by indicating there levels of agreement in a 5-point Likert scale. Table 11 shows the responses gathered from this section, and the frequency of influence the perceived benefits had on the project.

It was observed that $96 \%$ of the respondents agreed that LPS identifies and addresses potential problems before they become obstacles. In the same vein, $86 \%$ agreed that LPS reduces the incidence of bad news and completes project on schedule. However, only $32 \%$ of the respondents accepted to the benefits that LPS develops supervisory skills, reducing the load on management. Similarly, $50 \%$ accepted that LPS creates a more predictable and reliable production program, with the remaining $50 \%$ disagreed.

59\% agreed on Last Planner System's ability to deliver the project more safely faster and at a reduced cost. Similarly, 68\% admitted that it stabilizes projects and support other lean actions, while $82 \%$ identified that Last Planner System had the potential to improve construction logistics on projects.

Additionally, 45\% respondents indicated that Last Planner System has the benefit of improving predictions of labour required within any project. However, $50 \%$ agrees that it is able to reduce the risk of catastrophic loss while $50 \%$ disagreed on this opinion. And finally $100 \%$ of the respondents agreed on its ability to complete project on schedule.

TABLE XI: Benefits of the Implementation (Section D)

\begin{tabular}{|c|c|c|c|c|c|c|c|c|c|c|c|c|}
\hline \multirow[b]{2}{*}{ Sr.No. } & \multirow[b]{2}{*}{ Benefits } & \multicolumn{11}{|c|}{ Weighting Frequency (F) } \\
\hline & & 1 & 2 & 3 & 4 & 5 & $\sum \mathbf{F}$ & $\overline{\mathbf{x}}$ & RII & Rank & Rating & $\begin{array}{c}\% \\
\text { Rating } \\
\end{array}$ \\
\hline 01. & $\begin{array}{l}\text { Solve Problems on } \\
\text { time. }\end{array}$ & 0 & 0 & 1 & 12 & 9 & 22 & 4.36 & 0.87 & 1 & $\begin{array}{l}\text { Very } \\
\text { High } \\
\text { rating }\end{array}$ & 96 \\
\hline 02. & $\begin{array}{c}\text { Reducing the } \\
\text { incidence of bad } \\
\text { news \& to get what } \\
\text { bad news there is } \\
\text { early. }\end{array}$ & 0 & 0 & 3 & 12 & 7 & 22 & 4.18 & 0.84 & 3 & $\begin{array}{l}\text { High } \\
\text { rating }\end{array}$ & 86 \\
\hline 03. & $\begin{array}{c}\text { Developing } \\
\text { Supervisory skills } \\
\text { \& reducing the load } \\
\text { on Management. }\end{array}$ & 0 & 5 & 10 & 6 & 1 & 22 & 3.14 & 0.63 & 10 & $\begin{array}{l}\text { High } \\
\text { rating }\end{array}$ & 32 \\
\hline 04. & $\begin{array}{c}\text { Creating a more } \\
\text { predictable } \& \\
\text { reliable production } \\
\text { program. }\end{array}$ & 0 & 2 & 9 & 6 & 5 & 22 & 3.63 & 0.73 & 7 & $\begin{array}{l}\text { High } \\
\text { rating }\end{array}$ & 50 \\
\hline 05. & $\begin{array}{l}\text { Delivering projects } \\
\text { more safely, faster } \\
\text { \& at reduced costs. }\end{array}$ & 0 & 3 & 6 & 9 & 4 & 22 & 3.63 & 0.73 & 6 & $\begin{array}{l}\text { High } \\
\text { rating }\end{array}$ & 59 \\
\hline 06. & $\begin{array}{l}\text { Stabilize projects \& } \\
\text { support other lean } \\
\text { actions. }\end{array}$ & 0 & 0 & 8 & 10 & 4 & 22 & 3.81 & 0.76 & 5 & $\begin{array}{l}\text { High } \\
\text { rating }\end{array}$ & 68 \\
\hline 07. & $\begin{array}{l}\text { Improving } \\
\text { Construction } \\
\text { Logistics on } \\
\text { Projects. }\end{array}$ & 1 & 0 & 3 & 12 & 6 & 22 & 4 & 0.8 & 4 & $\begin{array}{l}\text { Very } \\
\text { High } \\
\text { rating }\end{array}$ & 82 \\
\hline 08. & $\begin{array}{c}\text { Improving } \\
\text { Predictions of } \\
\text { Labour Required. }\end{array}$ & 1 & 2 & 9 & 7 & 3 & 22 & 3.4 & 0.68 & 9 & $\begin{array}{l}\text { High } \\
\text { rating }\end{array}$ & 45 \\
\hline 09. & $\begin{array}{l}\text { Reduces the risk of } \\
\text { Catastrophic Loss. }\end{array}$ & 0 & 4 & 7 & 6 & 5 & 22 & 3.54 & 0.71 & 8 & $\begin{array}{l}\text { High } \\
\text { rating }\end{array}$ & 50 \\
\hline 10. & $\begin{array}{l}\text { Completes projects } \\
\text { on Schedule. }\end{array}$ & 0 & 0 & 0 & 15 & 7 & 22 & 4.32 & 0.86 & 2 & $\begin{array}{l}\text { Very } \\
\text { High } \\
\text { rating }\end{array}$ & 100 \\
\hline
\end{tabular}




\section{CONCLUSION}

It was observed that Contractor produced substantial results in terms of time, cost and quality performances. The contractor completed the construction project two months before than the actual completion date allocated to the project. The contractor had a better allocation of resources, an organized flow and access of materials and this reduced interference amongst working teams by making all the team members aware of what to do and when to do each assignment.

Although the project suffered from shortage of materials, the problem of material shortage was overcome by engaging in short term and look ahead planning together with regularly doing a constraint analysis to envisage possible constraints to the project before they occur.

Thus implementation of Last Planner System helped the project team to receive information regularly of the project success and failures during weekly meetings. It also analyzed the findings from the survey questionnaire to assess participants' views of the process. On the whole, they agreed that LPS had a significant and positive impact on the whole project management.

\section{REFERENCES}

[1] Ahiakwo, O., Oloke, D. and Suresh, S (2014). “ Improving Project Planning and Control in Construction by implementing Last Planner Systems in Nigeria. "International Council for Research and Innovations in Building and Construction (CIB W107 2014) 28th - 30th January 2014, Lekki Lagos, Nigeria.

[2] AlSehaimi,AbdullahO., Tzortzopoulos,Patricia and Koskela,Lauri (2013). "Improving construction management practice with the Last Planner System: a case study.” Engineering, Construction and Architectural Management, Vol. 21, No. 1. pp. 5164,DOI: 10.1108/ECAM-03-2012-0032.

[3] Aziz, R. F., \& Hafez, S. M. (2013). “Applying lean thinking in construction and performance improvement.”Alexandria Engineering Journal, Vol. 52, No. 4, pp. 679-695, DOI :http://dx.doi.org/10.1016/j.aej.2013.04.008.

[4] Ballard, G., Kim, Y.W., Jang, J.W., and Liu, M. (2007). Road Map for Lean Implementation at the Project Level, Research Report 234-11, Construction Industry Institute, The University of Texas at Austin, Texas, USA, 426.

[5] Ballard, G., \& Howell, G. (2004). An Update on Last Planner, Proc. 11th Annual Conf. Intl. Group for Lean Construction, Blacksburg, Virginia, USA, 13.

[6] Ballard, G. and Howell, G.A.(2003) Competing construction management paradigms. Lean Construction Journal, 1(1), pp. 38-45

[7] Ballard, G., and Howell, G. A. (1998). "Shielding Production: Essential Step in Production Control.”Journal of Construction Engineering and Management, Vol. 124, No.1,pp.11-17, DOI:10.1061/(ASCE)0733-9364(1998)124:1(11).

[8] Bierly, P. E., and Hämäläinen, T. (1995). “Organizational learning and strategy.”Scandinavian Journal of Management, Vol. 11, No. 3, pp. 209-224. DOI: 10.1016/0956-5221(95)00011-j.

[9] Daeyoung Kim and Hee-Sung Park (2006).”Innovative construction management method: Assessment of lean construction implementation.” KSCE Journal of Civil Engineering, KSCE, Vol. 10, No. 6, pp. 381-388, DOI: 10.1007/BF02823976.

[10] Fernando, L. B., Alvarez, and Eugenia, M. (2005). "Last Planner: An advance in planning and controlling construction projects - Case study in the city of Medellin." Proc. IV Sibragec I Elagec, Porto Alegre, Brazil, http://bdigital.eafit.edu.co/Libreria/PonenciaIVSibragec.pdf (June 2010).

[11] Glenn Ballard and Gregory A. Howell. (2003), “Lean project management.” Building Research \& Information, Taylor \& Francis Ltd, Vol.31, No.2, pp. 119-133, DOI: 10.1080/0961321031000083922.

[12] Gonzalez, V., Alarcon, L. F., and Mundaca, F. (2008). "Investigating the relationship between planning reliability and project performance.”Production Planning \& Control,Vol. 19No.5, pp. 461-474. DOI: 10.1080/09537280802059023.

[13] Hamzeh, F.R. (2009). Improving Construction Workflow - The Role of Production Planning and Control, PhD Dissertation, University of California at Berkeley, Berkeley, CA, 273.

[14] Hamzeh, F.R. (2011). "The Lean Journey: Implementing the Last Planner System inConstruction”, Proceedings of the 19th Annual Conference of the International Groupfor Lean Construction, IGLC 19, 13-15 July, Lima, Peru, pp. $379-390$

[15] Hevner, A. R., March, S. T., Park, J., and Ram, S. (2004). Design Science in Information Systems Research. MIS Quarterly, 28(1), 75105.

[16] Koskela, L. (1992). “Application of the New Production Philosophy to Construction”. Tech. Report No. 72, CIFE, Stanford Univ., CA.

[17] Koskela, L. (2008) Which kind of science is construction management? Proceedings of the $16^{\text {th }}$ International Group for Lean Construction (IGLC) Conference, July 2008, Manchester, UK.

[18] Koskela, L., Howell, G., and Ballard, G., (2003) “Achieving Change in Construction”, Proceedings of the 11th Annual Conference of the International Group for Lean Construction, 2003, Virginia Tech, Blacksburg, Virginia, U. S. A., pp. 1 - 14.

[19] Koskela, L., Howell, G., Ballard, G., and Tommelein, I. (2002). "The Foundations of Lean Construction.” Design and Construction: Building in Value, R. Best, and G. de Valence, eds., Butterworth-Heinemann, Elsevier, Oxford, UK.

[20] Koskela, L., Stratton, R. and Koskenvesa, A. (2010) Last planner and critical chain in construction management: comparative analysis. Haifa, Israel: National Building Research Institute, Technion-Israel Institute of Technology, pp. 538-547.

[21] Liu, M., and Ballard, G. (2009). "Factors affecting work flowreliability-A case study.” Proc. of the 17th Annual Conference ofthe International Group for Lean Construction, National PingtungUniv.of Science \& Technology, Taiwan, 657-666.

[22] Liker, J. (2004). The Toyota Way, McGraw-Hill, New York.

[23] Mossman, Alan (2013) Last Planner®: $5+1$ crucial \& collaborative conversations for predictable design \& construction delivery. http://bit.ly/LPS-5cc (22-Apr-13)

[24] M.A. Marhani, A. Jaapar, N.A.A. Bari, Lean construction: towards enhancing sustainable construction in Malaysia, J. Procedia Social Behav. Sci. 68 (2012) 87-98.

[25] Ojo, E., Mbowa, C., and Akinlabi, E. T (2014), "BarriersImplementing Green Supply Chain Management in Construction industry.” Proceedings of the 2014 International Conference on Industrial Engineering and Operations Management Bali, Indonesia, January 7 9, 2014.

[26] Patel, A (2011) The Last Planner System for reliable project delivery. M.sc Thesis at the University of Texas at Arlington,

[27] Paton, R.A., Paton, R. and McCalman, J. (2008) Change management: A guide to effective implementation .Sage Publications Ltd.

[28] Raghavan, N., and Satyanarayana, K.N. (2011). "Lean Construction - an Introduction to Concepts, Principles \& Practices". The Masterbuilder, Oct, 2011. 
[29] Raghavan, N., Kalidindi, S., Mahalingam, A., Varghese, K., and Ayesha, A. (2014). "Implementing Lean Concepts on Indian Construction Sites: Organisational Aspects and Lessons Learned.”Proceedings of the 22nd annual conference of the International Group for Lean Construction, Oslo, 1181-1190.

[30] Seppänen, G. Ballard, and S. Pesonen, The Combination of Last Planner System and Location-Based Management System, Lean Construction Journal, (2010) 6 (1) 43-54.

[31] Sacks, R., and Goldin, M. (2007). "Lean management model for construction of high-rise apartment buildings." Journal of Construction Engineering and Management." Vol.133, No.5, pp.374.384, DOI:http://dx.doi.org/10.1061/(ASCE)07339364(2007)133:5(374).

[32] Salem, O., Genaidy, J. S. A., and Minkarah, I. (2006). "Lean Construction : From Theory to Implementation." Journal of management in engineering, Vol. 22, No. 4, pp.1-21. DOI: http://dx.doi.org/10.1061/(ASCE)0742-597X(2006)22:4(168).

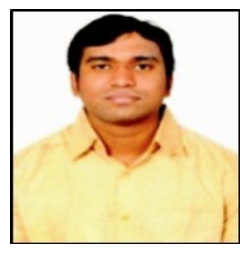

\section{ABOUT THE AUTHORS}

S M Abdul Mannan Hussain is currently pursuing his Ph.D from Gitam University, Hyderabad campus. He is also working as a Associate Professor in the Department of Civil Engineering, Malla Reddy Engineering College. He has worked as a Project Management Consultant Engineer in TCA Consultants Pvt. Ltd. He also worked as Assistant Professor in Muffakham Jah College of Engineering \& Technology. He has very good Industrial knowledge and also extensive teaching skills in Construction Engineering \& Management, Estimation and Costing, Watershed Management \& Building Materials construction \& Planning. He has published 20 research papers at International Journals, 8 research papers in International \& National Conferences.

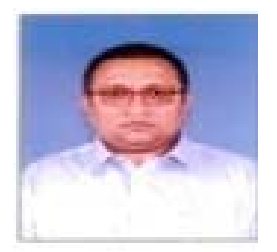

Dr. Seshadri Sekhar. T. is a Professor and Dean of NICMAR Hyderabad Campus, Telangana, India. He holds an M.Tech in Structural Engineering and $\mathrm{PhD}$ in Structural Engineering from JNTU, Hyderabad. He is specialized in structural engineering and his research interests are concrete technology, structural design, high performance concrete, prefabricating structures, special concretes and use of micro silica, fly ash in building materials. Guided 4 Ph.D candidates Presently 8 P. hD candidates are working under his supervision. His research interests are concrete technology; high performance concrete, special concretes and Lean Construction. He is a member of ISTE, Fellow of ICI and Fellow of Institution of Engineers.

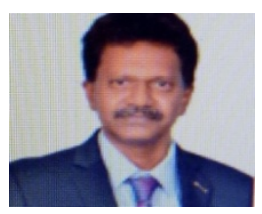

Dr. B.S.R.K. Prasad is a Professor \& HOD in Civil Engineering Department, GITAM University, Hyderabad. He received his Ph. D Structural Engineering from JNTU, Hyderabad, Telangana, India. He received his B. Sc in Civil Engineering from NIT, Kurukshetra, Haryana and ME in Structural Engineering from Gulbarga University, Karnataka. His areas of interest are Size effect, fracture analysis to civil engineering materials, FEM analysis. 